\title{
Loss of heterozygosity at chromosome 6 q correlates with tumor progression and patient survival
}

\author{
GUDRUN BRAGADOTTIR, GUDNY EIRIKSDOTTIR, ASGEIR SIGURDSSON, ROSA B. BARKARDOTTIR, \\ JULIUS GUDMUNDSSON, JON GUNNLAUGUR JONASSON and SIGURDUR INGVARSSON
}

Department of Pathology, University Hospital of Iceland, Box 1465, IS-121 Reykjavik, Iceland

Received June 20, 1995; Accepted August 5, 1995

\begin{abstract}
Several chromosome regions exhibit loss of heterozygosity $(\mathrm{LOH})$ in human breast carcinoma and are thought to carry tumor suppressor genes. We have analysed human breast tumors with 9 polymorphic microsatellite markers that are specific to chromosome $6 \mathrm{q}$. The mapping of smallest region of overlap (SRO) indicated location of candidate suppressor genes at $6 \mathrm{q} 23$ and $6 \mathrm{q} 27$. Variations in estrogen receptor (ER) expression were independent of the number of copies of the corresponding gene. Tumors with and without $\mathrm{LOH}$ on chromosome $6 \mathrm{q}$ were tested for association with clinicopathological factors. A significant association was found between $\mathrm{LOH}$ at $6 \mathrm{q}$ and the following: high S-phase, aneuploidy, deletions at chromosomes $3 p$ and $9 \mathrm{p}$ and lower survival rate. In a multivariate model $\mathrm{LOH}$ at $6 \mathrm{q}$ is an independent prognostic variable and patients having tumors with $\mathrm{LOH}$ have approximately twofold increase in relative risk of death. It can be concluded that the $6 \mathrm{q}$ deletions give additional prognostic information that might be useful in breast cancer treatment.
\end{abstract}

\section{Introduction}

Breast cancer is the most common malignancy in women. It affects nearly $10 \%$ of all Caucasian women, its incidence is increasing worldwide. Irrespective of advances in therapy, the death rate has not decreased (1). Malignant transformation is envisioned as a multistep process. Activation of oncogenes and/or inactivation of tumor suppressor genes have been observed in the progression of many tumor types, including breast tumors.

The frequent finding of loss of heterozygosity ( $\mathrm{LOH}$ ) for a specific chromosomal marker in tumor DNA compaired to normal DNA suggests the presence of a tumor suppressor gene. In primary breast tumors, frequent $\mathrm{LOH}$ has been detected on chromosome arms 1p (2), 1q (3), 3p (4,5), 6q (6), 11p and $11 q(7), 13 q(8), 16 q(9), 17 p(10), 17 q$ and 18q (11). Some of these frequently deleted regions contain known tumor suppressor genes.

Correspondence to: Dr S. Ingvarsson, Department of Pathology, University Hospital of Iceland, Box 1465, IS-121 Reykjavik, Iceland

Key words: breast cancer, chromosome 6, loss of heterozygosity, survival, microsatellite markers
$\mathrm{LOH}$ on $6 \mathrm{q}$ has been reported in various cancer types other than breast tumors e.g. ovarian cancer $(12,13)$, malignant melanoma (14), renal cell carcinoma $(15,16)$, small cell lung cancer (17), primitive neuroectodermal tumors (18), and B-cell non-Hodgkins lymphoma $(19,20)$.

Microcell mediated transfer of chromosome 6 into breast cancer cell lines lacking a normal chromosome 6 have been shown to induce alterations of in vitro growth properties and suppress tumorigenicity of the cells (21). Chromosome 6 has also been shown to suppress tumorigenicity of cell lines derived from endometrial carcinoma (22), and malignant melanoma (23) when transferred into these cells. Welch et al (24), showed that by injecting a normal chromosome 6 into a highly metastatic malignant melanoma cell line the ability of the cells to metastasize in athymic nude mice was suppressed but the cells remained tumorigenic.

The frequent LOH on $6 \mathrm{q}$ in several tumor types and the ability of a normal chromosome 6 to suppress tumorigenicity and metastatic properties of carcinoma cells suggests that this chromosome contains one or more tumor suppressor genes that play a role in tumor development and progression. This gives reason to focus on $6 \mathrm{q}$ in the search for putative tumor suppressor genes important in tumorigenesis.

In this study highly polymorphic DNA markers on $6 \mathrm{q}$ were used to screen 204 pairs of breast tumor DNA and normal DNA for loss of heterozygosity (LOH) in an attempt to find a common region of frequent deletions which could harbor a putative tumor suppressor gene. We also tested whether LOH correlated with certain clinicopathological variables such as tumor steroid receptor content, histological type, patient lymph node status at diagnosis, tumor size, age at diagnosis, S-phase fraction and ploidy and loss of heterozygosity on other chromosomal arms $(3 p, 9 p, 11 p$, $11 \mathrm{q}, 16 \mathrm{q}, 17 \mathrm{p}$ and $17 \mathrm{q})$.

\section{Materials and methods}

Samples and collection. Tumor samples from patients diagnosed with primary breast cancer were sent to our labarotory for estrogen receptor and progesterone receptor analysis, using a ligand binding assay. Blood samples were collected in EDTA from the patients. Tumor and blood samples were stored at $-70^{\circ} \mathrm{C}$ until they are processed for DNA extraction. All information about the tumors e.g. tumor size, tumor type and node status was recorded by the 
Table I. Markers used and frequency of LOH.

\begin{tabular}{|c|c|c|c|c|c|}
\hline Marker & $\begin{array}{c}\text { Distance } \\
\mathrm{cM}^{\mathrm{a}}\end{array}$ & Location & $\begin{array}{c}\text { Number of } \\
\text { samples tested }\end{array}$ & $\begin{array}{l}\text { Informative } \\
\text { samples }\end{array}$ & $\begin{array}{c}\text { Tumors } \\
\text { with } \\
\text { LOH \% }\end{array}$ \\
\hline D6S262 & 9 & $6 q 22.3-q 23.1$ & 174 & 135 & 21 \\
\hline D6S292 & 11 & $6 q 16.3-q 23.2$ & 86 & 67 & 36 \\
\hline D6S311 & 9 & $6 q 21-q 23.3$ & 182 & 166 & 25 \\
\hline D6S290 & 1 & $6 q 21-q 25.2$ & 180 & 117 & 28 \\
\hline ESR & 10 & $6 \mathrm{q} 25.1$ & 165 & 145 & 18 \\
\hline D6S305 & 11 & $6 q 25.2-q 27$ & 116 & 92 & 22 \\
\hline D6S264 & 4 & $6 \mathrm{q} 25.2-\mathrm{q} 27$ & 177 & 126 & 29 \\
\hline D6S297 & 13 & $6 q 27$ & 82 & 42 & 24 \\
\hline D6S281 & & $6 q 27$ & 156 & 113 & 23 \\
\hline
\end{tabular}

aMarkers ordered according to the genetic map provided by GDB.

Department of Pathology at the National University Hospital of Iceland.

DNA extraction. Normal DNA was extracted from peripheral blood leukocytes according to the method described by Miller et al (25). Tumor DNA was extracted either from the nuclear pellet after cytosol removal for hormone receptor analysis or from the pulverized primary tumor itself according to the method described by Maniatis et al (26).

PCR analysis of microsatellites. Paired blood and tumor DNA was subjected to PCR analysis. "able I lists the microsatellite PCR primers used. They were obtained from the Nordic Primer Bank in Uppsala. Information about regional location of the primers was obtained from the Department of Clinical Genetics at the University Hospital in Uppsala and the Genome Data Base in Baltimore. The primers were end labelled with $\gamma^{32} \mathrm{P}-\mathrm{ATP}$ using T4-PNK. DynaZyme ${ }^{\mathrm{TM}}$ polymerase was used in the buffer solution supplied with the enzyme. PCR products were electrophoresed on $6.5 \%$ denaturing polyacrylamide gels and then subjected to autoradiography and interpreted by 2 reviewers.

Statistical analysis. The Chi-square test was used to determine whether any correlation exists between allelic imbalance on $6 \mathrm{q}$ and certain clinicopathological variables. These clinicopathological variables and the cut-off levels used are listed in Table II. Survival analysis was made according to the Kaplan Meier method. Survival curves were compared by the log-rank test. The Cox's partially non-parametric regression model was used for multivariate analysis.

\section{Results}

Loss of heterozygosity ( $\mathrm{LOH}$ ) on $6 q$. We analysed pairs of normal DNA and tumor DNA from 204 breast cancer patients for $\mathrm{LOH}$, using 9 polymorphic DNA markers localized to the
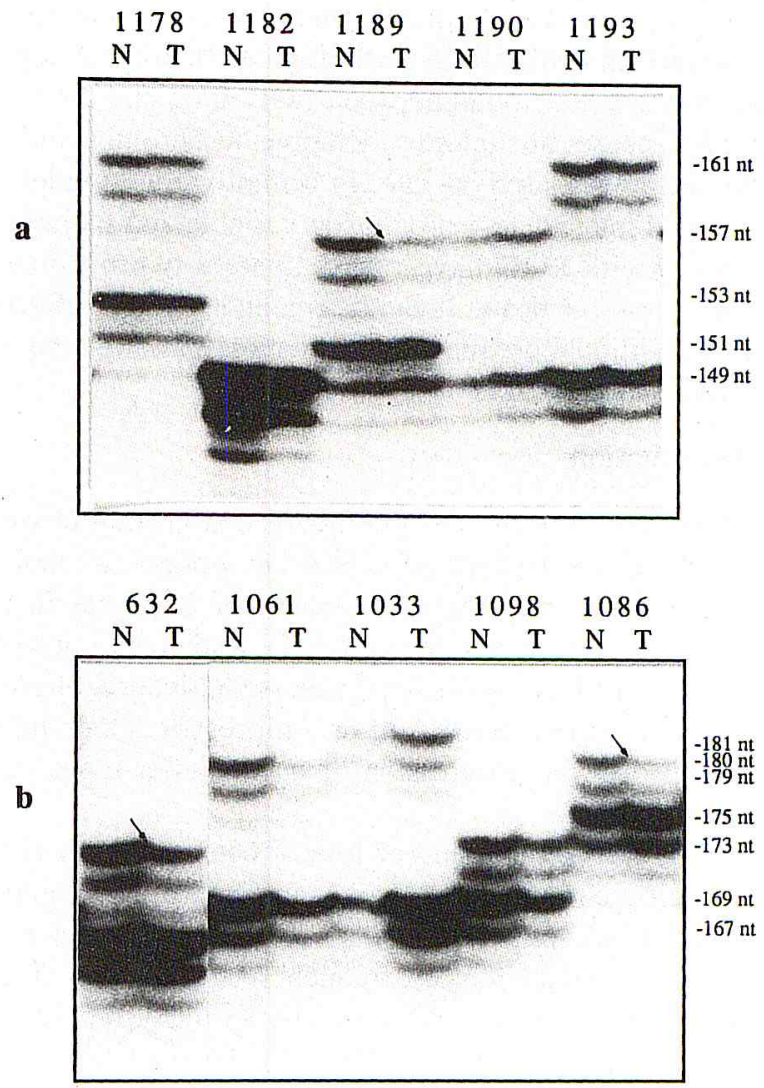

Figure 1. Dinucleotide repeat polymorphism in selected matched normal $(\mathrm{N})$ and tumor $(\mathrm{T})$ tissue from breast cancer patients. The microsatellite markers D6S292 (a) and D6S262 (b) were used in PCR analysis and the ${ }^{32} \mathrm{P}$-labelled amplification products separated in $6.5 \%$ polyacrylamide, $8 \mathrm{M}$ urea denaturing gels. Case numbers are shown at the top. Numbers to the right indicate allele sizes in nucleotides (nt). LOH can be seen with D6S292 in case 1189 and with D6S262 in cases 632 and 1086, indicated by arrows. Case 1182 is homozygous with marker D6S292 while other cases are normal heterozygotes. 


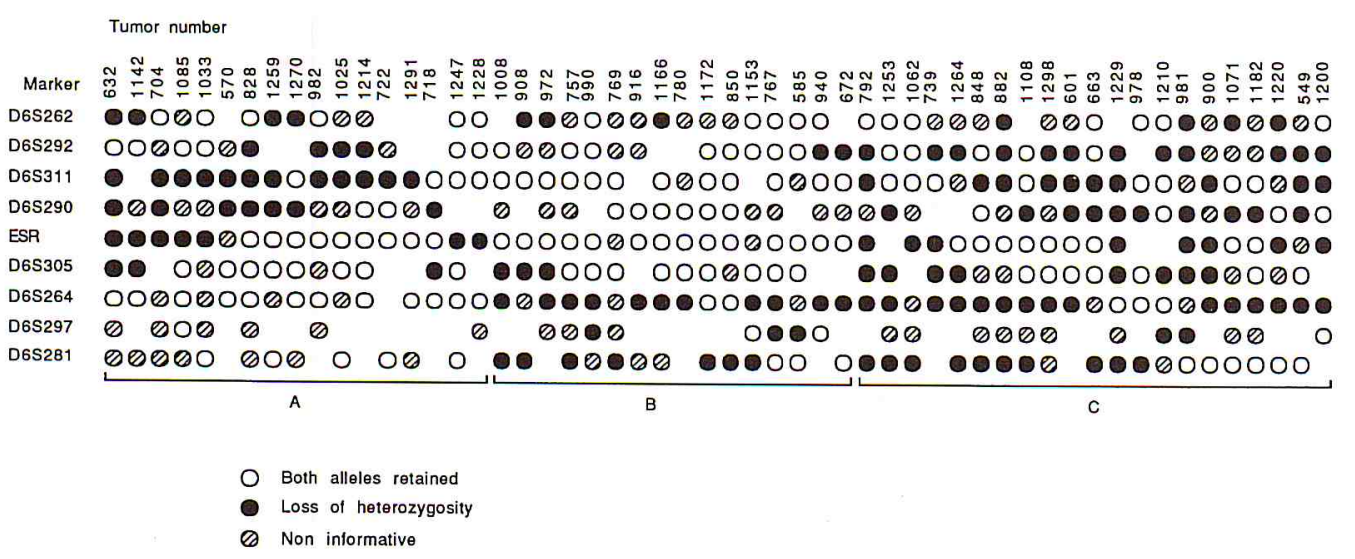

Figure 2. Patterns of allelic deletions on chromosome $6 \mathrm{q}$ for 54 breast carcinomas. These are selected tumors with partial and interstitial deletions on chromosome 6q. Group A is concordant with a smallest region of overlap (SRO) between markers D6S311 and D6S290. Group B is concordant with a SRO between markers D6S264 and D6S297. Group C is consistent with SRO at both regions.

Table II. Chi-square analysis comparing loss of heterozygosity (LOH) on $6 \mathrm{q}$ of tumor DNA to other categorized prognostic factors.

\begin{tabular}{|c|c|c|c|}
\hline Variable & LOH/Total & $\%$ & $\mathrm{P}$ \\
\hline All & $84 / 204$ & 41 & \\
\hline $\begin{array}{l}\text { S-phase } \\
\text { low }(<7) \\
\text { high }(>7) \\
\text { no information }\end{array}$ & $\begin{array}{l}32 / 105 \\
47 / 81 \\
5 / 18\end{array}$ & $\begin{array}{l}31 \\
58\end{array}$ & $<0.001^{* * * *}$ \\
\hline $\begin{array}{l}\text { Ploidy } \\
\text { diploid } \\
\text { aneuploid } \\
\text { no information }\end{array}$ & $\begin{array}{l}25 / 77 \\
56 / 116 \\
3 / 11\end{array}$ & $\begin{array}{l}33 \\
48\end{array}$ & $0.029 *$ \\
\hline $\begin{array}{l}\text { Node status } \\
\text { negative } \\
\text { positive } \\
\text { no information }\end{array}$ & $\begin{array}{l}44 / 122 \\
40 / 82 \\
1 / 1\end{array}$ & $\begin{array}{l}36 \\
49\end{array}$ & 0.071 \\
\hline $\begin{array}{l}\text { Histological type } \\
\text { ductal } \\
\text { lobular } \\
\text { no information }\end{array}$ & $\begin{array}{l}78 / 183 \\
5 / 19 \\
1 / 2\end{array}$ & $\begin{array}{l}43 \\
26\end{array}$ & 0.169 \\
\hline $\begin{array}{l}\text { PgR fmol/mg protein } \\
\geq 25 \\
<25 \\
\text { no information }\end{array}$ & $\begin{array}{l}42 / 111 \\
37 / 83 \\
5 / 10\end{array}$ & $\begin{array}{l}38 \\
45\end{array}$ & 0.345 \\
\hline $\begin{array}{l}\text { ER fmol/mg protein } \\
\geq 10 \\
<10 \\
\text { no information }\end{array}$ & $\begin{array}{l}59 / 149 \\
22 / 48 \\
3 / 7\end{array}$ & $\begin{array}{l}40 \\
46\end{array}$ & 0.445 \\
\hline $\begin{array}{l}\text { Tumor size } \\
<2 \mathrm{~cm} \\
\geq 2 \mathrm{~cm} \\
\text { no information }\end{array}$ & $\begin{array}{l}35 / 82 \\
49 / 118 \\
0 / 4\end{array}$ & $\begin{array}{l}43 \\
42\end{array}$ & 0.870 \\
\hline $\begin{array}{l}\text { Age } \\
<50 \text { year } \\
\geq 50 \text { year }\end{array}$ & $\begin{array}{l}30 / 72 \\
54 / 132\end{array}$ & $\begin{array}{l}42 \\
41\end{array}$ & 0.916 \\
\hline
\end{tabular}

$* * *=99.9 \%$ confidence interval. $*=95 \%$ confidence interval. long arm of chromosome 6. Fig. 1 shows representative autoradiograms documenting $\mathrm{LOH}$ detected in breast tumor samples.

Eighty-four of the 204 samples showed LOH with at least one marker used in the study $(41 \%)$. Frequencies of LOH at each of the 9 markers tested at chromosome 6 are summarized in Table I. LOH for individual markers ranged from 18-36\%. The markers ESR located at 6q25.1 and D6S305 located at 6q25.2-q27 gave the lowest percentage of abnormality.

A high percentage of abnormality was detected with markers localized at 6q22-q23 and 6q27 (Table I). Of the 84 tumors, 23 showed LOH for all informative markers on $6 \mathrm{q}$, suggesting a major loss of the long arm of chromosome 6 . The remaining 61 tumors showed partial and interstitial deletions (Fig. 2). In view of the high proportion of $\mathrm{LOH}$ (Table I) and the smallest region of overlap (SRO) (Fig. 2), two regions with deletions on chromosome $6 \mathrm{q}$ are detected. These two SROs are located between markers D6S311 and D6S290 and markers D6S264 and D6S297, respectively.

Loss of heterozygosity on $6 q$ and correlation to clinicopathological variables. The clinicopathological variables and the cut-off levels used are listed in Table II. A significant association was found between $\mathrm{LOH}$ on $6 \mathrm{q}$ and high tumor S-phase fraction with $58 \%$ of tumors with high S-phase having $\mathrm{LOH}$ on $6 \mathrm{q}$ but $31 \%$ of tumors with low S-phase $(\mathrm{p}<0.001)$. A significant correlation was also found between LOH on $6 \mathrm{q}$ and aneuploidy, with $48 \%$ of aneuploid tumors with $\mathrm{LOH}$ on $6 \mathrm{q}$ but $33 \%$ of diploid tumors $(\mathrm{p}=0.029)$. There was no significant association between $\mathrm{LOH}$ on $6 \mathrm{q}$ and the other parameters tested (Table II).

LOH on $6 q$ and association with LOH on other chromosome arms. At our laboratory chromosome regions 3p, 9p, 11p, 11q, $16 q, 17 p$ and $17 q$ have been analyzed in sporadic breast cancer with microsatellite markers. A strong significant association was found between $\mathrm{LOH}$ on $6 \mathrm{q}$ and $\mathrm{LOH}$ on $3 p$ and $9 \mathrm{p}$ and a significant association was also observed between LOH on $6 q$ and LOH on 11q, 17p and 17q (Table IV).

Survival analysis. A significant prognostic separation of survival curves was detected in relation to $\mathrm{LOH}$ at $6 \mathrm{q}$ (Fig. 3). 
Table III. Multivariate analysis (proportional-hazard (Cox) regression) of survival in patients with breast cancer.

Factor

\begin{tabular}{lccc} 
& $\begin{array}{c}\text { Univariate } \\
\text { p-value }\end{array}$ & $\begin{array}{c}\text { Multivariate } \\
\text { p-value }\end{array}$ & $\begin{array}{c}\text { RR } \\
\text { (with 95\% CI) }\end{array}$ \\
\hline Tumor size & 0.004 & 0.021 & $2.40(1.14-5.05)$ \\
$6 q$ LOH & 0.013 & 0.039 & $1.95(1.03-3.66)$ \\
PgR & 0.040 & 0.110 & $1.65(0.89-3.05)$ \\
Axillary nodal involvement & 0.018 & 0.187 & $1.51(0.82-2.78)$ \\
S-phase fraction & 0.014 & 0.690 & $1.14(0.61-2.13)$ \\
\hline
\end{tabular}

Factors were categorized as shown in Table II. According to this model tumor size and 6q LOH are independent predictors of hazard. $\mathrm{RR}=$ relative hazard of dying.

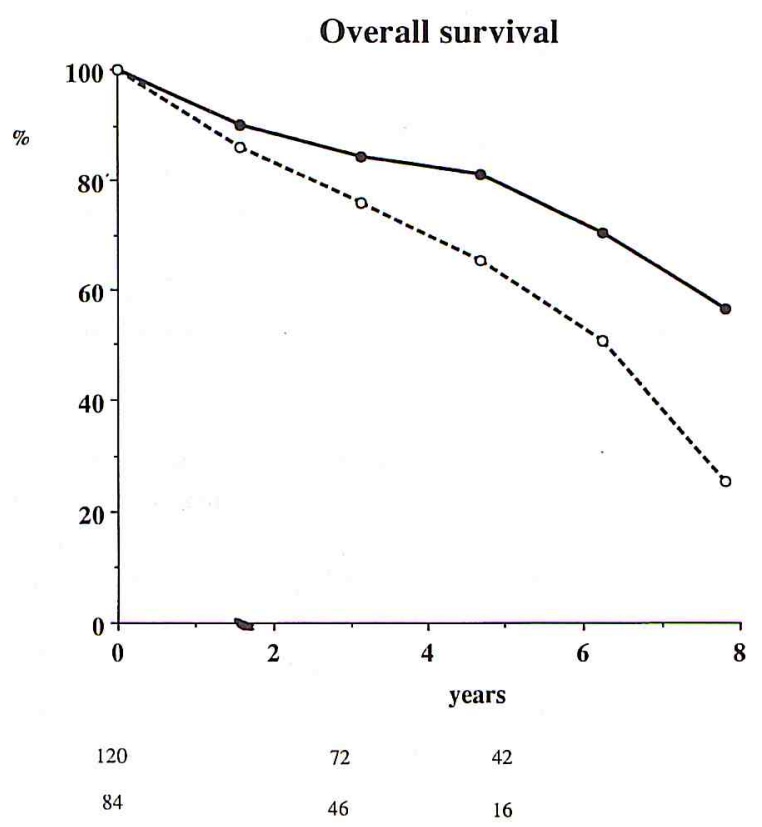

Figure 3. Overall survival. The number of patients at risk at time $0,2.5$ years and 5 years is shown for both categories. - , patients without 6q LOH; ---, patients with $6 \mathrm{q} \mathrm{LOH}$.

After 5 years of follow-up there was $38 \%$ mortality among patients with $\mathrm{LOH}$ at $6 \mathrm{q}$ but only $20 \%$ among those without $6 \mathrm{q} \mathrm{LOH}(\mathrm{p}=0.013)$. The possible clinical relevance of $6 \mathrm{q} \mathrm{LOH}$ as a prognostic factor in breast cancer was evaluated with multivariate analyses. The patients having tumors with $6 \mathrm{q} \mathrm{LOH}$ had a 1.95 fold increase in relative mortality rate compared with patients without $6 \mathrm{q} \mathrm{LOH} \mathrm{(Table} \mathrm{III).}$

\section{Discussion}

In this study $\mathrm{LOH}$ on chromosome $6 \mathrm{q}$ was detected with at least one marker in $41 \%$ of the tumors examined. These observations are in accordance with the findings of other researchers (6). The elevated frequency of $\mathrm{LOH}$ with certain
Table IV. Correlation of $\mathrm{LOH}$ at $6 \mathrm{q}$ and $\mathrm{LOH}$ at other chromosome regions.

\begin{tabular}{llc}
\hline & $\mathrm{p}$ value & $\mathrm{n}$ \\
\hline $3 \mathrm{p}$ & $<0.001 * * *$ & 117 \\
$9 \mathrm{p}$ & $<0.001 * * *$ & 140 \\
$11 \mathrm{p}$ & 0.165 & 70 \\
$11 \mathrm{q}$ & $0.029 *$ & 85 \\
$16 \mathrm{q}$ & 0.757 & 152 \\
$17 \mathrm{p}$ & $0.022 *$ & 75 \\
$17 \mathrm{q}$ & $0.016 *$ & 79 \\
\hline
\end{tabular}

( $\mathrm{n}=$ number of samples tested). $* * *=99.9 \%$ confidence interval. $*=95 \%$ confidence interval.

markers and the mapping of smallest region of overlap (SRO) suggests two regions with deletions, at 6q21-23 and 6q25-27, indicating the location of candidate tumor suppressor genes. These two regions are also deleted in ovarian tumorigenesis, further supporting the presence of tumor suppressor genes (27).

Estrogen receptor content of a breast tumor is an indicator of differentiation. High ER content predicts improved disease-free survival and the likelihood of benefit from tamoxifen therapy. A number of estrogen receptor variants have been described in breast tumors (28). We found no significant association between loss of heterozygosity on $6 \mathrm{q}$ and estrogen receptor content of the tumor. These results are in accordance with earlier reports $(29,30)$. This seems to compare to similar observations regarding $\mathrm{LOH}$ at chromosome $11 \mathrm{q}$ and lack of association with $\mathrm{PgR}$ gene expression $(7,29,30)$. One copy of these hormone receptor genes seems to be sufficient for the receptor expression. Mechanisms other than loss of heterozygosity on chromosome $6 \mathrm{q}$ seem to cause loss of estrogen receptor 
expression in breast cancer cells. Abnormal methylation of a certain region in the ER gene is a mechanism that has been proposed (31). A low percentage of abnormality was detected with the marker ESR which is located in the estrogen receptor gene (32). We can not conclude from our results that the gene for the estrogen receptor plays a role as a tumor suppressor gene.

Measures of the proliferation activity of tumor cells have prognostic value in patients with node-negative breast cancer (33). $\mathrm{LOH}$ on $6 \mathrm{q}$ was found to be significantly correlated with high tumor S-phase fraction and tumor aneuploidy. These findings suggest that $\mathrm{LOH}$ at $6 \mathrm{q}$ is associated with cell proliferation and an instable genome. We found no significant association between $\mathrm{LOH}$ at $6 \mathrm{q}$ and common prognostic factors such as patients age at diagnosis, tumor size, progesterone receptor content, histological type and degree of axillary involvement at diagnosis.

A significant separation of survival curves was detected in relation to $\mathrm{LOH}$ at $6 \mathrm{q}$, patients with $\mathrm{LOH}$ at $6 \mathrm{q}$ having worse prognosis. In a multivariate analysis $\mathrm{LOH}$ at $6 \mathrm{q}$ and tumor size were found to be independent prognostic variables and patients having tumors with $\mathrm{LOH}$ were found to have approximately a twofold increase in relative risk of death from the disease. This suggests that $\mathrm{LOH}$ at $6 \mathrm{q}$ might be useful as an independent prognostic factor.

Some studies have revealed that certain $\mathrm{LOH}$ events occur in preferred combinations e.g. $3 p$ and $17 p(6), 13 q$ and $17 p$ $(1,34,35), 11 \mathrm{p}$ and $17 \mathrm{p}(36) . \mathrm{LOH}$ on $6 \mathrm{q}$ was significantly correlated with LOH on chromosome arms $3 p$ and $9 p$. These combinations of $\mathrm{LOH}$ events in cells could result in a growth selection during cancer progression. Preferred combinations of tumor suppressor gene deletions might result in enhanced tumor growth. These results should however be interpreted cautiously in functional terms since as Devilee and Cornelisse (37) have pointed out they might be coincidental with the fact that some of the regions mentioned above are among the most intensively studied in breast cancer.

Our results show that $\mathrm{LOH}$ at $6 \mathrm{q}$ is common in breast cancer. LOH has significant correlation with some of the clinicopathological factors and has an independent prognostic value. It can be concluded that $6 \mathrm{q}$ deletions give additional prognostic information. Further investigation should reveal whether this finding can assist in treatment of the disease.

\section{Acknowledgements}

The authors wish to thank professor Jonas Hallgrimsson and Valgardur Egilsson for providing pathological material. We are also grateful to Bjarni Agnarsson and Helgi Sigurdsson for results on flow cytometry. Also thanks to Sigurlaug Skirnisdottir for providing genomic DNA for the analysis, to Trausti Baldursson for results on $\mathrm{LOH}$ at chromosome 17 and to Jon Thor Bergthorsson and Solveig Björling for results on hormone receptor analysis. The Nordic primer bank that provided the microsatellite markers is supported by the Nordic Council of Ministers. This work was supported by the Students' innovation fund, Nordic Cancer Union, Icelandic Cancer Society, the Science Fund of Iceland, the Science Fund of the University Hospital of Iceland and the Memorial Fund of Bergthora Magnusdottir and Jakob B. Bjarnason.

\section{References}

1. Sato T, Akiyama F, Sakamoto G, Kasumi F and Nakamura Y: Accumulation of genetic alterations and progression of primary breast cancer. Cancer Res 51: 5794-5799, 1991.

2. Genuardi M, Tsihira H, Anderson DE and Saunders GF: Distal deletion of chromosome $1 \mathrm{p}$ in ductal carcinoma of the breast. Am J Hum Genet 45: 73-82, 1989.

3. Gendler SJ, Cohen EP, Craston A, Duhig T, Johnstone G and Barnes D: The locus of the polymorphic epithelial mucin (PEM) tumor antigen on chromosome 1q21 shows a high frequency of alteration in primary human breast tumors. Int J Cancer 45: 431-435, 1990.

4. Eiriksdottir G, Bergthorsson JT, Sigurdsson H, Gudmundsson J, Skirnisdottir S, Egilsson V, Barkardottir RB and Ingvarsson S: Mapping of chromosome 3 alterations in human breast cancer using microsatellite PCR markers: correlation with clinical variables. Int J Oncol 6: 369-375, 1995.

5. Bergthorsson JT, Eiriksdottir G, Barkardottir RB, Egilsson V, Arason A and Ingvarsson S: Linkage analysis and allelic imbalance in human breast cancer kindreds using microsatellite markers from the short arm of chromosome 3. Hum Genet (In press).

6. Devilee P, Van Vliet M, Van Sloun P, Kuipers-Dijkshoorn NJ, Hermans J, Pearson PL and Cornelisse CJ: Allelotype of human breast carcinoma: a second major site for loss of heterozygosity is on chromosome 6q. Oncogene 6: 1705-1711, 1991.

7. Gudmundsson J, Barkardottir RB, Eiriksdottir G, Arason A, Egilsson V and Ingvarsson S: Correlation of prognostic factors with genetic alterations on chromosome 11 in human breast cancer: two possible deletion regions on 11q. Br J Cancer (In press).

8. Larsson C, Byström C, Skoog L, Rotstein S, Nordenskjöld M: Genomic alterations in human breast carcinomas. Genes Chromosomes Cancer 2: 191-197, 1990.

9. Skirnisdottir S, Eiriksdottir G, Baldursson T, Barkardottir RB, Egilsson V and Ingvarsson S: High frequency of allelic imbalance at chromosome region 16q22-q23 in human breast cancer: correlation with high PgR and low S-phase. Int J Cancer 64: 112-116, 1995.

10. McKay J, Steel CM, Elder PA, Forrest APM and Evans HJ: Allele loss on the short arm of chromosome 17 in breast cancer. Lancet 2: 1384-1385, 1988.

11. Cropp CS, Lidereau R, Campell G, Champeme MH and Callahan R: Loss of heterozygosity on chromosomes 17 and 18 in breast carcinoma: two additional regions identified. Proc Natl Acad Sci USA: 87: 7737-7741, 1990.

12. Saito S, Saito H, Koi S, Sagae S, Kudo R, Saito J, Noda K and Nakamura Y: Fine scale deletion mapping of the distal long arm of chromosome 6 in 70 human ovarian cancers. Cancer Res 52: 5815-5817, 1992.

13. Foulkes WD, Ragoussis J, Stamp GWH, Allan GJ and Trowsdale J: Frequent loss of heterozygosity on chromosome 6 in human ovarian carcinoma. Br J Cancer 67: 551-559, 1993.

14. Millikin D, Meese E, Vogelstein B, Witkowski C and Trent J: Loss of heterozygosity for loci on the long arm of chromosome 6 in human malignant melanoma. Cancer Res 15: 5449-5453, 1991.

15. Morita R, Ishikawa J, Tsutsumi M, Hikiji K, Tsukada Y, Kamidono S, Maeda S and Nakamura Y: Allelotype of renal cell carcinoma. Cancer Res 51: 820-823, 1991.

16. Morita R, Saito S, Ishikawa J, Ogawa O, Yoshida O, Yamakawa K and Nakamura Y: Common regions of deletion on chromosome $5 q, 6 q$ and $10 \mathrm{q}$ in renal cell carcinoma. Cancer Res 51: 5817-5820, 1991

17. Merlo A, Gabrielson E, Mabry M, Vollmer R, Baylin S and Sidransky D: Homozygous deletion on chromosome $9 p$ and loss of heterozygosity on 9q, 6p and $6 \mathrm{q}$ in primary human small cell lung cancer. Cancer Res 54: 2322-2326, 1994.

18. Thomas $\mathrm{G}$ and Raffel C: Loss of heterozygosity on $6 \mathrm{q}, 16 \mathrm{q}$ and $17 \mathrm{p}$ in human central nervous system primitive neuroectodermal tumors. Cancer Res 51: 639-643, 1991.

19. Gaidano G, Hauptschein RS, Parsa NZ, Offit K, Rao PH, Lenoir G, Knowles DM, Chaganti RSK, Dalla-Favera R: Deletions involving two distinct regions of $6 \mathrm{q}$ in B-cell non-Hodgkin lymphoma. Blood 80: 1781-1787, 1992.

20. Offit K, Parsa NZ, Gaidano G, Filippa DA, Louie D, Pan D, Jhanwar SC, Dalla-Favera R, Chaganti RS: 6q deletions define distinct clinico-pathologic subsets of non-Hodgkin's lymphoma. Blood 82: 2157-2162, 1993. 
21. Negrini M, Sabbioni S, Possati L, Rattan S, Corallini A, BarbantiBrodano $G$ and Croce C: Suppression of tumorigenicity of breast cancer cells by microcell-mediated chromosome transfer: studies on chromosomes 6 and 11. Cancer Res 54: 1331-1336, 1994.

22. Yamada H, Wake N, Fujimoto S, Barret J and Oshimura M: Multiple chromosomes carrying tumor suppressor activity for a uterine endometrial carcinoma cell line identified by microcellmediated chromosome transfer. Oncogene 5: 1141-1147, 1990.

23. Trent JM, Stanbridge EJ, McBride HL, Meese EU, Casey G, Araujo DE, Witkowski CM, Nagle RB: Tumorigenicity in human melanoma cell lines controlled by introduction of human chromosome 6. Science 247: 568-571, 1990.

24. Welch DR, Chen P, Miele ME, McGary CT, Bower JM, Stanbridge EJ, Weissman BE: Microcell-mediated transfer of chromosome 6 into metastatic human C8161 melanoma cells suppresses metastasis but does not inhibit tumorigenicity. Oncogene 9: 255-262, 1994

25. Miller SA, Dykes DD and Polesky HF: A simple salting out procedure for extracting DNA from human nucleated cells. Nucl Acids Res 16: 1215, 1988.

26. Maniatis T, Fritsch EF and Sambrook J: Molecular cloning: A labaratory manual. Cold Spring Laboratory Press, New York, 1982.

27. Orphanos V, McGown G, Hey Y, Thorncroft M, SantibanezKoref M, Russell SEH, Hickey I, Atkinson RJ and JM Boyle: Allelic imbalance of chromosome $6 \mathrm{q}$ in ovarian tumors. Br J Cancer 71: 666-669, 1995.

28. McGuire WL, Chamness G and Fuqua S: Estrogen receptor variants in clinical breast cancer. Mol Endocrinol 81: 1571-1575, 1991.

29. Magdelenat H, Gerbault-Seureau M, Laine-Bidron C, Prieur M and Dutrillaux B: Genetic evolution of breast cancer: II. Relationship with estrogen and progesterone receptor expression. Breast Cancer Res Treat 22: 119-127, 1992.
30. Magdelenat H, Gerbault-Seureau M and Dutrillaux B: Relationship between loss of estrogen and progesterone receptor expression and of $6 \mathrm{q}$ and $11 \mathrm{q}$ chromosome arms in breast cancer. Int $\mathrm{J}$ Cancer 57: 63-66, 1994

31. Ottaviano YL, Issa JP, Parl FF, Smith HS, Baylin SB and Davidson NE: Methylation of the estrogen receptor gene $\mathrm{CpG}$ island marks loss of estrogen receptor expression in human breast cancer cells. Cancer Res 54: 2552-2555, 1994.

32. Senno L, Aguiari G and Piva R: Dinucleotide repeat polymorphism in the human estrogen receptor (ESR) gene. Hum Mol Genetics 1: 354, 1992.

33. Sigurdsson H, Baldetorp B, Borg A, Dalberg M, Fernö M, Killander D and Olsson $\mathrm{H}$ : Indicators of prognosis in nodenegative breast cancer. New Engl J Med 322: 1045-1053, 1990.

34. Andersen TI, Gaustad A, Farrants GW, Nesland JM, Tweit KM and Borresen AL: Genetic alterations of the tumor suppressor gene regions $3 \mathrm{p}, 11 \mathrm{p}, 13 \mathrm{q}, 17 \mathrm{p}$ and $17 \mathrm{q}$ in human breast carcinoma. Genes Chromosomes Cancer 4: 113-121, 1992.

35. Borg A, Zhang QZ, Alm P, Olsson H and Sellberg G: The retinoblastoma gene in breast cancer: allele loss is not correlated with loss of gene protein expression. Cancer Res 52: 2991-2994, 1992.

36. Takita KI, Sato T, Miyagi M, Watatani M, Akiyama F, Sakamoto G, Kasumi F, Abe R and Nakamura Y: Correlation of loss of alleles on the short arm of chromosomes 11 and 17 with metastasis of primary breast cancer to lymph nodes. Cancer Res 52: 3914-3917, 1992.

37. Devilee $\mathrm{P}$ and Cornelisse CJ: Somatic genetic changes in human breast cancer. Biochim Biophys Acta 1198: 113-130, 1994. 